\title{
INCLUSION POLICY IN EAST JAVANESE CULTURAL PERSPECTIVE AND ITS IMPLICATION ON GUIDANCE AND COUNSELING
}

\author{
Asep Sunandar*, Ediyanto, Fina Riswari, Fiolina Hana Puspitasari, Neny \\ Yuniarti, Silvana Rahma Iswahyudi \\ *Correspondent Author
}

\author{
Asep Sunandar \\ Universitas Negeri Malang \\ Jalan Semarang Nomor 5, Sumbersari, \\ Lowokwaru, Kota Malang, \\ Indonesia \\ Email: asep.sunandar.fip@um.ac.id \\ Ediyanto \\ Universitas Negeri Malang \\ Jalan Semarang Nomor 5, Sumbersari, \\ Lowokwaru, Kota Malang, \\ Indonesia \\ Fina Riswari \\ Universitas Negeri Malang \\ Jalan Semarang Nomor 5, Sumbersari, \\ Lowokwaru, Kota Malang, \\ Indonesia \\ Fiolina Hana Puspitasari \\ Universitas Negeri Malang \\ Jalan Semarang Nomor 5, Sumbersari, \\ Lowokwaru, Kota Malang, \\ Indonesia

\section{Neny Yuniarti} \\ Universitas Negeri Malang \\ Jalan Semarang Nomor 5, Sumbersari, \\ Lowokwaru, Kota Malang, \\ Indonesia \\ Silvana Rahma Iswahyudi \\ Universitas Negeri Malang \\ Jalan Semarang Nomor 5, Sumbersari, \\ Lowokwaru, Kota Malang, \\ Indonesia \\ Page \\ 29-34
}

ABSTRACT
The urgency of inclusive policies in a very diverse crosscultural perspective is a form of follow-up to the implementation of inclusive education that provides equal and equal educational services to all children with diverse cultural backgrounds. The purpose of the inclusion policy study in the cultural perspective of East Java is to find out how the implementation of inclusion policies can represent the cultural diversity that exists in East Java. The implementation of inclusion policies is not only for disabilities, but also the implementation of inclusion policies is able to reach into various aspects of life that are developing in the people of East Java. This literature review aims to summarize how the concept of inclusion policy is in the perspective of East Java culture. The selection of articles started from peer-reviewed research journals at Google Scholar and Z-library. From this search, 14,700 articles were found. Then after screening the articles published from 2010 to 2020 and found 1045 articles. There were 10 articles that were studied and analyzed according to the topic discussed. The analysis technique used is content analysis. Based on the results of the analysis, it can be seen that it is necessary to implement inclusive education policies to improve the quality of life for persons with disabilities and individuals. Through formal education in the cultural perspective in East Java, it is expected to be able to overcome the diversity of social and cultural dimensions. The existence of a policy on inclusive education can realize the implementation of public services in the field of education and other fields that respect diversity and is not discriminatory for all individual learners. The implication of the results of this study is guidance and counseling teachers are required to have competence in providing services for children with disabilities.

Keywords: inclusion policy, east java culture, special need children 


\section{0| PSIKOPEDAGOGIA}

JURNAL BIMBINGAN DAN KONSELING

Vol.10, No.1, June 2021

\section{INTRODUCTION}

Inclusive education opens the gate for an education system that accepts all students in the same class by providing an appropriate program while suiting each students' ability and needs (Herawati, 2016; Mahat, 2008; Garnida, 2015; Ni'matuzahroh \& Nurhamida, 2016; Ediyanto, Atika, Kawai, Prabowo, 2017). Regarding the implementation of inclusive education, the Indonesian government issues Law no. 20 of 2003, particularly article 15 on children with special needs. The stipulation is then supported by the National Regulation of Minister of Education of the Republic of Indonesia (Permendiknas RI) no. 70 of 2009 on Inclusive education (Alhaddad, 2020). East Java Provincial government supports the inclusive education program by issuing a governor regulation no. 16 of 2011 on inclusive education implementation (Isnadi and Mukafan, 2020).

The concept of inclusive education is inseparable from disability development. Isnadi and Mukafan's (2020) literature review cites Mike Oliver's view of the disability concept within a social context, stating that disability as a category is only understood by a framework that believes the disability is culturally created and socially structured, such social model is developed to broaden the disabled persons' opportunities to participate in the socio-cultural life. In Herawati's (2016) literature review, Parkay and Standford suggest that multicultural education is also based on the fact that students do not learn in an empty space, as their culture may affect how they learn. Therefore, a learning activity should be designed based on a local cultural foundation, in this case, is East Java culture.

East Java is one of the Indonesian provinces rich in cultural, social, and language diversity. Diversity is inseparable from the life of East Java people. However, as found in Madurese ethnic with their language diversity, diverse language variation can affect children with disability or those outside their community, thus creating exclusivity. In this regard, inclusion policy can represent an acceptable and respected form of diversity.
Viewing inclusive policies from diverse, multicultural perspectives is necessary to understand the concept and efforts done in this field to cope with East Java's cultural diversity. It is also important to understand how inclusive education implementation can equally serve children from different cultures in order to deliver fair educational services. Inclusion can be seen as a process to answer and respond to diversity through increasing participation in learning, culture, and community activities to reduce exclusivity in education activities. This literature review sums the concept of inclusion policy from East Java cultural perspectives and how its implementation can accommodate students learning needs based on local culture.

\section{RESEARCH METHOD}

This qualitative literature review aimed to provide a depiction regarding the current studies in this topic by reviewing peerreviewed articles published between 20102020. The data were analyzed using Milles and Huberman's technique. This study consisted of three stages: selecting fields, analysis, and categorization. Ten relevant peer-reviewed articles were selected, retrieved from Google Scholar and Z-library. The search was filtered only to show peerreviewed articles with full-text available. The keyword used was "konsep pendidikan inklusi pada perspective budaya", resulting in 14,700 articles. Out of these articles, 1045 works were published between 2010-2020. The final filter used was "Pendidikan inklusif Dalam budaya Jawa Timur," resulting in 19 national and international articles, narrowed down to the ten most relevant articles to be reviewed. The selected articles consisted of eight international articles and two national articles. One person with four verification criteria analyzed the selected journal based on the research question. Each article was then reviewed further based on the predetermined research questions. Each article used as a reference in this study was considered relevant to the study and deemed able to answer the research questions. 


\section{RESULTS AND DISCUSSIONS}

Ten articles relevant to the research topic are reviewed and analyzed. Based on the analysis, it is necessary to implement inclusive education policy in formal education to cope with social and cultural diversity (Khanal, 2014). By applying Contextually Appropriate Practices (CAP) (Nganga, et al,. 2020; Piliouras \& Evangelou, 2012). It is also important to apply an appropriate strategy by considering a child's cultural background literacy to develop solidarity. It can be internalized by explicitly teaching about the contextual shift to help students perform a transition from their personal culture to the school culture by applying the following sociocultural principles and strategy: 1)Inquiry as the principle in administering curricular activities, 2) Developing a collaborative community, 3) applying discursive strategy as the students' learning framework, 4) designing activities that bridge daily-life and scientific languages (Piliouras \& Evangelou, 2012).

Table 1

Inclusion Policy in Cultural Perspective

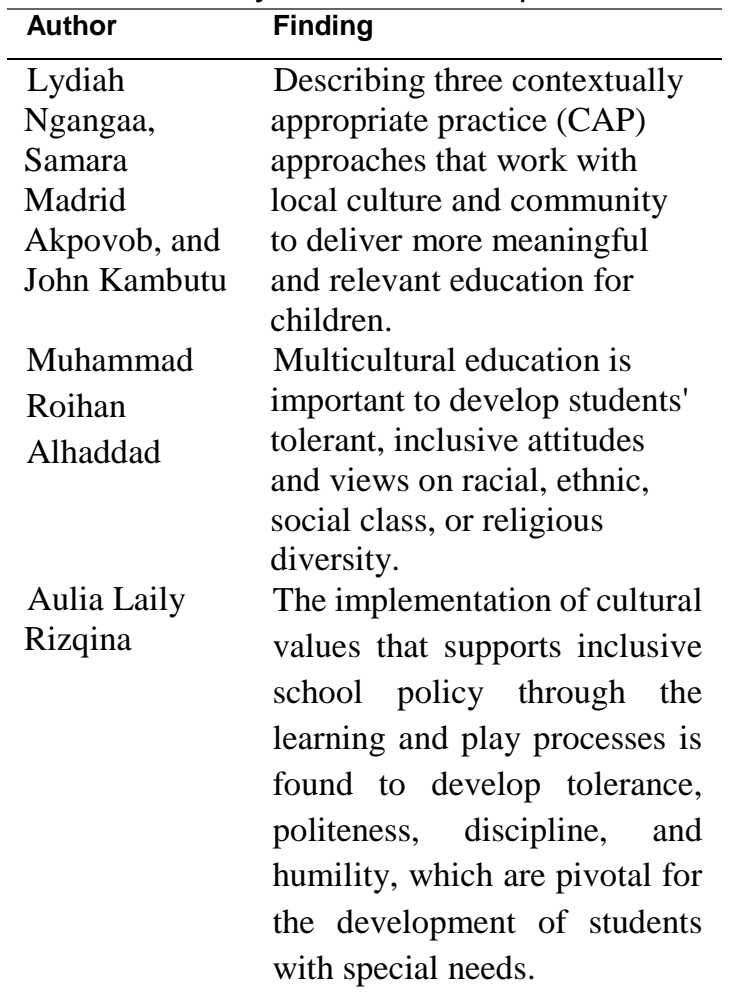

Damodar Developing more inclusive

Khanal education regulation and multi-dimensional approach among rural communities with economic disadvantages.

Eman Gaad Cultural understanding is a cornerstone of cultural change. That change will lead to inclusive education understanding in regular schools. It is important to respect diversity while calling for equality.

Panagiotis Implementing appropriate Piliouras \& strategy to help students shift Odysseas from their own culture to the Evangelou school culture to make it more meaningful and relevant for them.

Isnadi and Inclusion administration in the Mukafan rural area is still suboptimal due to limited facilities and infrastructures, and human resources, causing the fulfillment of disabled individuals' rights to be hampered.

Asyhabuddin The implementation of serial prayer tradition as three social inclusive pillar can prevent conflict due to religious diversity.

Arif Maftuhin An inclusive city refers to a disability-friendly city, which can be measured using four indicators: participation, available services for people with disability, right fulfillment efforts, and citizens' inclusive attitude. Thus, the disabled persons' right fulfillment is not only limited to education service but also political, economic, cultural, sports, and art rights, as stated in Law no. 8 of 2016.

Rimmerman Developing three frameworks to conceptualize disability.

The concept of inclusive education represents all aspects of openness in accepting children with special needs to obtain their basic rights as citizens. Inclusive education is a concept that accommodates all children with special needs who face writing and reading difficulties. (Ilahi, 2013). As the public understanding develops, inclusion policy is no longer limited only to disability 


\section{2 | PSIKOPEDAGOGIA}

JURNAL BIMBINGAN DAN KONSELING

Vol.10, No.1, June 2021

(Isnadi dan Mukafan, 2020). Rimmerman conceptualized three frameworks. The first is the moral/religious model that dominated before the 20th century. The second model is the medical model. The third model is the social model that delivers the inclusion concept to broaden the disabled persons' opportunity to actively participate in social and cultural life. (Rimmerman, 2013). ocial diversity emerges based on these models and creates social inclusion (Asyhabuddin, 2020). Social inclusion can be realized if its three pillars are implemented, including social acceptance (attitude), policy (institutional) and access and participation (environment) (Maftuhin, 2017). This social inclusion should cover not only the disability aspect in education services but also all elements and aspects of the community such as politics, economy, arts, culture, and sports.

Culture-based inclusive education can internalize cultural and character values. The internalization of cultural values in inclusive education is also done through traditional games (Rizqina, 2019). The multicultural, inclusive education paradigm is expected to eliminate stereotypes, egoistic, individualistic, and exclusive attitudes and views among students with disability. The multicultural education process is expected to help students identify the culture, nation, and global community (Zainiyati, 2007). This is also relevant to $\mathrm{Ki}$ Hajar Dewantara's (Suparlan, 2015) view that the learning process should adopt the national culture or the concept that suits the national condition instead of foreign learning models.

Inclusive education should internalize cultural values to children during the learning process. Cultural recognition also belongs to the inclusive learning process since it allows children to respect one another and be familiar with cultural values. The cultural values that uphold virtues can help children develop noble character. When such values are implemented in the educational context, they can develop students' character and is integrated into other developmental aspects (Budiyanto, 2017; Liana et al.,

2018).
Culture represents a human ideal process or condition. It describes individuals' way of life that represents meaning and values not only in arts and learning activities but also in the institution and daily behavior. School is a part of culture reflecting and representing the best and the worst cultures. In other words, it is a microcosm of the broader community with different ideologies and practices. Therefore, it is difficult to change certain schools and make them accept individuals with special needs without changing the cultural context where the school is located. It should be noted and understood why this is not an easy task. A school is a cultural system that stabilizes and organizes human activities, providing a blueprint of social participation. In the school cultural system, every activity is thoroughly designed because the education environment can significantly influence children's development. In an inclusive educational institution, a learning model also serves as a method in developing children's potential.

Children should recognize their culture from the kindergarten level so that they will not be separated from their community. Play methods in rural areas commonly aim to develop children's senses. Children's play can be in the form of dance or simple drama. Ki Hadjar Dewantara stated that art used as a learning medium in Tamansiswa aimed to develop children's sense of beauty to create a civilized and cultural individual. Ki Hadjar Dewantara (Suparlan, 2015) stated that children's development occurs "from nature to culture."

In guidance and counseling service, inclusion policy in East Javanese culture is also applicable. School counselors can provide guidance and counseling services to children with special needs. In providing such services, school counselors can internalize East Javanese cultural values. For instance, they can perform a puppet show to provide a guidance service for children with special needs. The theme or figures in the show can adapt East Javanese folklores in order to internalize the characters to children with special needs. School counselors can also apply play techniques when conducting 
guidance services. One of the East Javanese traditional games applicable in guidance service for children with special needs is "Jamuran," which can be used to develop teamwork skills of children with special needs.

\section{CONCLUSION}

East Java is a province with cultural, social, and language diversity. This province has implemented inclusive education that considers disability aspects in many different fields such as arts, culture, politics, economy, and sports. Inclusive education is a movement that aims to create an equal educational environment for all students regardless of their socio-economic, gender, sexual orientation, ethnic, racial, and cultural backgrounds. The implementation of inclusive education can deliver a non-discriminative education that respects diversity for all students. Inclusion policy in East Javanese cultural perspective is applicable in guidance and counseling service for students with special needs. It can be done by internalizing values in East Javanese culture to develop the character of students with special needs.

\section{REFERENCE}

Alhaddad, R,M,. (2020). Konsep Pendidikan Multikultural dan Pendidikan Inklusi. Jurnal Tarbiyah Islamiyah, 5 (1).

Asyhabuddin, A. (2020). Tradisi Doa Berantai dan Inklusi Sosial Keagamaan di Desa Kepung Kabupaten Kediri. IBDA: Jurnal Kajian Islam dan Budaya, 18(1), 139-153.

Budiyanto. (2017). Pengantar Pendidikan Inklusif Berbasis Budaya Lokal. Bandung: Prenada Media Group

Ediyanto, E., Atika, I. N., Kawai, N., \& Prabowo, E. (2017). Inclusive education in Indonesia from the perspective of Widyaiswara in Centre for Development and empowerment of teachers and education personnel of kindergartens and special Education. IJDS: Indonesian Journal of Disability Studies, 4(2), 104-116.

Gaad, E. (2004). Cross-Cultural Perspectives On The Effect of Cultural Attitudes Towards Inclusion For Children With Intellectual Disabilities. International Journal of Inclusive Education, 8(3), 311-328.
Garnida, D. (2015). Pengantar pendidikan inklusif. Bandung: Refika Aditama.

Herawati, N. I. (2016). Pendidikan Inklusif. EduHumaniora Jurnal Pendidikan Dasar Kampus Cibiru, 2(1), 1-11.

Ilahi, M. T., \& Rose, K. R. (2013). Pendidikan Inklusif: Konsep \& Aplikasi. Ar-ruzz Media. Yogyakarta.

Isnadi \& Mukafan. (2020). Pendidikan Inklusi Di Desa. Pesat, 6(5), 61-80.

Khanal, D, (2014). Children From The Dalit Community In Rural Nepal: A Challenge To Inclusive Education. International Journal of Inclusive Education, 19(7): 710-720.

Liana, H., dkk. (2018). Implementasi Pembelajaran Karakter Anak Usia Dini di Paud Anak Kita Preschool Samarinda. PENDAS MAHAKAM: Jurnal Pendidikan Dasar, 3(1), 8-19.

Maftuhin, A. (2017). Mendefinisikan Kota Inklusif: Asal-Usul, Teori dan Indikator. Tataloka, 19(2), 93-103.

Mahat, M. (2008). The Development of a Psychometrically-Sound Instrument To Measure Teachers' Multidimensional Attitudes Toward Inclusive Education. International Journal of Special Education, 23(1), 82-92.

Nganga, L., Madrid Akpovo, S., \& Kambutu, J. (2020). Culturally Inclusive and Contextually Appropriate Instructional Practices: Rethinking Pedagogical Perspectives, Practices, Policies, and Experiences in Early Childhood Education Programs. Journal of Research in Childhood Education, 34(1), 2-5.

Ni'matuzahroh, \& Nurhamida, Y. (2016). Individu Berkebutuhan Khusus Dan Pendidikan Inklusif. Penerbitan Universitas Muhammadiyah Malang.

Piliouras, P. \& Evangelou, O. (2012). Teachers' Inclusive Strategies to Accommodate 5th Grade Pupils' Crossing of Cultural Borders in Two Greek Multicultural Science Classrooms. Res Sci Educ, 42, 329351

Rimmerman, A. (2013). Social Inclusion of People With Disabilities: National And International Cambridge University Press.

Rizqina, L,A,. (2019). Golden Age: Pendidikan Inklusi Berbasis Budaya di Lingkungan PAUD Lab. FIP UNY Pedagogia. 


\section{4 | PSIKOPEDAGOGIA}

JURNAL BIMBINGAN DAN KONSELING

Vol.10, No.1, June 2021

Suparlan, H. (2015). Filsafat Pendidikan Ki Hadjar Dewantara dan Sumbangannya Bagi Pendidikan Indonesia. Jurnal Filsafat, 25(1), 5674.

Zainiyati, H. S. (2007). Pendidikan Multikultural: Upaya Membangun Keberagamaan Inklusif di Sekolah. ISLAMICA: Jurnal Studi Keislaman, 1(02), 135-145. 